\title{
A Polymorphism of Insulin-Like Growth Factor Binding Protein 2 Gene Associated with Growth and Body Composition Traits in Kampong Chickens
}

\author{
(KERAGAMAN GEN INSULIN-LIKE GROWTH FACTOR \\ BINDING PROTEIN 2 YANG BERASOSIASI DENGAN SIFAT \\ PERTUMBUHAN DAN KOMPOSISI TUBUH PADA AYAM KAMPUNG) \\ Ahmad Furqon ${ }^{1}$, Asep Gunawan ${ }^{2}$, Niken Ulupi ${ }^{2}$, \\ Tuti Suryati ${ }^{2}$, Cece Sumantri ${ }^{2,3}$ \\ ${ }^{1}$ Graduate School of Bogor Agricultural University, \\ ${ }^{2}$ Departmen of Animal Production and Technology, \\ Facultyy of Animal Science \\ ${ }^{3}$ Research Center for Bioresources and Biotechnology, \\ Bogor Agricultural University, \\ Jl. Agatis, Kampus IPB Dramaga, Bogor, West Java, Indonesia 16680 \\ Email: csumantri12@gmail.com. \\ Phone number: (0251) 8628379
}

\begin{abstract}
Insuline-like growth factor binding protein 2 (IGFBP2) is one of the principal binding proteins that has biological functions involved in growth, development, and differentiation. Selection for rapid growth based on molecular Marker Assisted Selection is required to increase production performance. The present study was designed to analyze the associations of IGFBP2 gene polymorphisms with chicken growth and body composition traits. Kampong chicken, a native chicken in Indonesia, is slow-growing chicken. A total of 59 males were used in the current study. Growth and body composition were measured in 24 wk of age. Primers for intron 2 region were designed from genomic chicken sequence. A c.1032C $>$ T SNP of the IGFBP2 gene intron 2 region was detected and PCR-RFLP method was then used to genotype Kampong chicken population. The result showed that IGFBP2 polymorphism was significantly associated with body, carcass, breast, breast muscle, pectoralis minor, leg, and wings weight in Kampong chicken population $(\mathrm{P}<0.05)$. The research suggests that the IGFBP2 gene could be a candidate gene that affects growth and body composition traits in chicken.
\end{abstract}

Keywords: kampong chicken; growth; body composition; insuline-like growth factor binding protein 2 gene; polymorphism

\begin{abstract}
Abstrak
Insuline-like growth factor binding protein 2 (IGFBP2) merupakan protein pengikat utama yang memiliki fungsi biologi terlibat dalam pertumbuhan, perkembangan, dan diferensiasi. Program seleksi untuk sifat pertumbuhan cepat berdasarkan penanda molekuler sangat diperlukan untuk meningkatkan performa produksi. Terkait hal tersebut, penelitian ini didesain untuk menganalisis asosiasi keragaman gen IGFBP2 dengan sifat pertumbuhan dan komposisi tubuh pada ayam kampung. Ayam Kampung merupakan ayam asli Indonesia dan tergolong ayam dengan pertumbuhan lambat. Sebanyak 59 ayam Kampung jantan digunakan dalam penelitian ini. Pertumbuhan dan komposisi tubuh diukur pada umur 24 minggu. Sepasang primer didesain pada daerah intron 2 berdasarkan sekuen genom ayam. Sebuah SNP c.1032C $>$ T pada gen IGFBP2 intron 2 dideteksi dan metode PCR-RFLP digunakan dalam menentukan genotype ayam Kampung. Hasil menunjukkan bahwa keragaman IGFBP2 signifikan berasosiasi dengan bobot badan, karkas, dada, otot dada, pectoralis minor, paha, dan sayap pada populasi ayam Kampung $(\mathrm{P}<0.05)$. Penelitian ini menyarankan gen IGFBP2 dapat dijadikan kandidat gen yang mempengaruhi sifat pertumbuhan dan komposisi tubuh pada ayam.
\end{abstract}

Kata-kata kunci: ayam kampung; pertumbuhan; komposisi tubuh; insuline-like growth factor binding protein 2 ; keragaman 


\section{INTRODUCTION}

Kampong chicken, a native chicken and one of genetic resources in Indonesia, has important roles in suplying egg and meat. Kampong chicken has no specific characteristics and usually raised free range in most rural area of Java, Indonesia (Nataamijaya, 2010; Riztyan et al., 2011). The selection for rapid growth in meattype chicken is required to increase production performance. This selection results in an increase of not only production performance but also physiological disorders (Deeb and Lamont, 2002). There is a negative correlation between production performance and fitness traits in the chickens (Martin et al., 1990). Selection in Kampong chickens usually is based on their phenotypic. It is difficult to increase the production performance and fitness traits simultaneously. Selection efficiency in production performance can be increased by using molecular marked-assisted selection (Li et al., 2003).

Insuline-like growth factors (IGF) are polypeptide that play an important role in cell growth and differentiation (Rechler, 1993). IGFbinding proteins extend the half-life of the IGFs and have shown to either inhibit or stimulate the growth promoting effects of the IGFs on cell culture. They change the interaction of IGFs with their cell surface receptors (Chesik et al., 2007).

There are 7 IGFBP that have been identified succesfully, and they were named IGFBP1 to IGFBP7 (Shimasaki and Ling, 1991; Oh et al., 1996). In mammals, these IGFBPs play a role in modulation of IGFs action by preventing insulin-like effects, regulation of halflife of IGFs in circulation, association with IGFs as carrier proteins and redistribution of IGFs between tissues and extracellular fluids (Kim et al., 2010). Insulin-like growth factor binding protein 2 (IGFBP2) is one of 7 IGFBP in serum of different species and binds IGF (Drop et al., 1992).

Previous studies have shown that some Single Nucleotide Polymorphisms (SNP) of IGFBP2 significantly affected growth traits (Lei et al., 2005; Sri-Sudaryati et al., 2013; Zhao et al., 2015). Leng et al. (2009) reported that a polymorphism of IGFBP2 in the 3;-flanking region was associated with abdominal fat. In addition, IGFBP2 level negatively affected bone size and mineral content in mice, which suggested that it was an important regulator of bone biology in vivo (Eckstein et al., 2002). Chicken IGFBP2 is highly expressed in many tissues of embryos, such as eye, muscle, brain, liver, heart, kidney, ovary and intestine (Schoen et al., 1995). Recently, IGFBP2 are detected by real-time Polymorphism Chain Reaction (rtPCR) technique in broiler chicken (Leach et al., 2006; Lu et al, 2010).

The objectives of the current study were to identify SNP in IGFBP2 gene intron 2 in Indonesian local chickens and to evaluate the associations between IGFBP2 SNP and traits of growth and body composition in Kampong chickens.

\section{RESEARCH METHODS}

\section{Experimental Populations and Mana- gement}

A total of 83 Kampong, 20 Merawang, 30 Sentul, 19 Pelung, and 9 broiler chickens were used in the current study to identify a polymorphism in IGFBP2 gene intron 2 . For association study, there were only 69 Kampong chickens used in this study. All chickens had access to feed and water ad libitum.. From hatch to 8 weeks of age, Kampong chickens received a starter feed $(4,080 \mathrm{kcal}$ of gross energy $/ \mathrm{kg}$ and $19,03 \%$ of crude protein) and from 9 to 24 weeks of age, Kampong chickens were fed a grower diet $(4,001 \mathrm{kcal}$ of gross energy $/ \mathrm{kg}$ and $17,42 \%$ of crude protein).

\section{Phenotypic Measurements}

Body weight and body composition traits were recorded at 24 weeks of age. These measurements included body weight (BW), carcass weight $(\mathrm{CW})$, breast weight $(\mathrm{BrW})$, breast muscle weight (BrMW), Pectoralis major weight (PmaW), Pectoralis minor weight (Pmiw), leg weight (LW), and wings weight (WW). All the traits were also expressed as a percentage of BW at 24 weeks of age.

\section{DNA Isolation and PCR Amplification}

Blood samples were collected from axillary vein. Genomic DNA were isolated according to Sambrook et al. (1989). The PCR primers of IGFBP2 gene intron 2 used in this study were based on previous study (Li et al., 2006). This primers (52 GTC CCA GAT AAA CCT TGC T 32; 52 GCT GGC AAG GGG TCT G 32) were designed to amplify a 367-bp fragment by Primer 5.0 (Premier Biosoft International, Palo Alto, CA) according to the chicken genomic sequence in the GenBank database (accession number AY 
326194). The PCR reaction conditions were $94^{\circ} \mathrm{C}$ for $5 \mathrm{~min}, 35$ cycles of $94^{\circ} \mathrm{C}$ for $10 \mathrm{~s}, 60^{\circ} \mathrm{C}$ for 20 $\mathrm{s}, 72^{\circ} \mathrm{C}$ for $30 \mathrm{~s}$, and an extension at $72^{\circ} \mathrm{C}$ for 5 $\mathrm{min}$. The $25-\mu \mathrm{L}$ reaction volume included $50 \mathrm{ng}$ of DNA template, $1 \times$ reaction buffer, $5 \mathrm{pmol}$ of each primer, $0.16 \mathrm{mM}$ of deoxyribonucleotide triphosphate, $1.5 \mathrm{mM}$ of $\mathrm{MgCl} 2$, and $1 \mathrm{U}$ of Taq polymerase.

Screening of the Population for Restriction Enzyme-Detectable SNP

A single nucleotide polymorphism (SNP) of the IGFBP2 gene was detected by digesting 7 $\mu \mathrm{L}$ of the $367 \mathrm{bp}$ PCR product with $3 \mathrm{U}$ of the Eco72 I enzyme (Thermo Fisher Scientific Inc., Lithuania) at $37^{\circ} \mathrm{C}$ overnight. The restriction digests were electrophoresed for $45 \mathrm{~m}$ at $100 \mathrm{~V}$ on a $2.0 \%$ agarose gel with ethidium bromide. Individual PCR-RFLP fragment sizes for the gene were determined by visualizing the band pattern under UV Transilluminator (AlphaImager $\left.{ }^{\circledR} \mathrm{EP}\right)$.

\section{Statistical Analysis}

The association between the polymorphism and the growth and body composition traits was analyzed using the GLM procedure (SAS Inst. Inc., Cary, NC). The model was fitted with the genotype of IGFBP2 gene intron 2 (G: 3 levels: CC, CT, TT) as fixed effects, as follows, $\mathrm{Y}=\mu+$ $\mathrm{G}+\mathrm{e}$; Where $Y$ is the dependent variable for trait measured in the population, $i$ is the overall population mean for traits, $G$ is the fixed effects, and $e$ is the random error. Significant differences between means of the different genotypes were calculated using the Duncan test. Significance was determined as $P<0.05$, unless otherwise specified.

\section{RESULTS AND DISCUSSION}

\section{Polymorphism in the Intron 2 Region of Chicken IGFBP2 Gene}

The present study identified a C/T SNP at base 1032 (accession number AY 326194) in the IGFBP2 gene intron 2 region. The polymorphism was associated with body composition traits of growing chickens. The examined SNP in intron region may either be causal or linked with functional polymorphisms of any region of the IGFBP2 gene or other nearby genes (Li et al., 2006). Introns play an important role in transcriptional regulation and genom structure (Chorev and Carmel, 2012). In addition, a C/A polymorphism was found in the 32 -flanking region of the IGFBP2 gene at base 1196 (accesion number U15086), this SNP associated with fatness traits (Leng et al., 2009).

A $367 \mathrm{bp}$ in length was succsessfully amplified by using PCR. There was a C/T SNP at base 1032 (accession number AY326194). The PCR-RFLP method was used successfully for genotyping the SNP in intron 2 of the chicken IGFBP2 gene. Three genotypes were detected and defined as CC, CT, and TT (Figure 1).

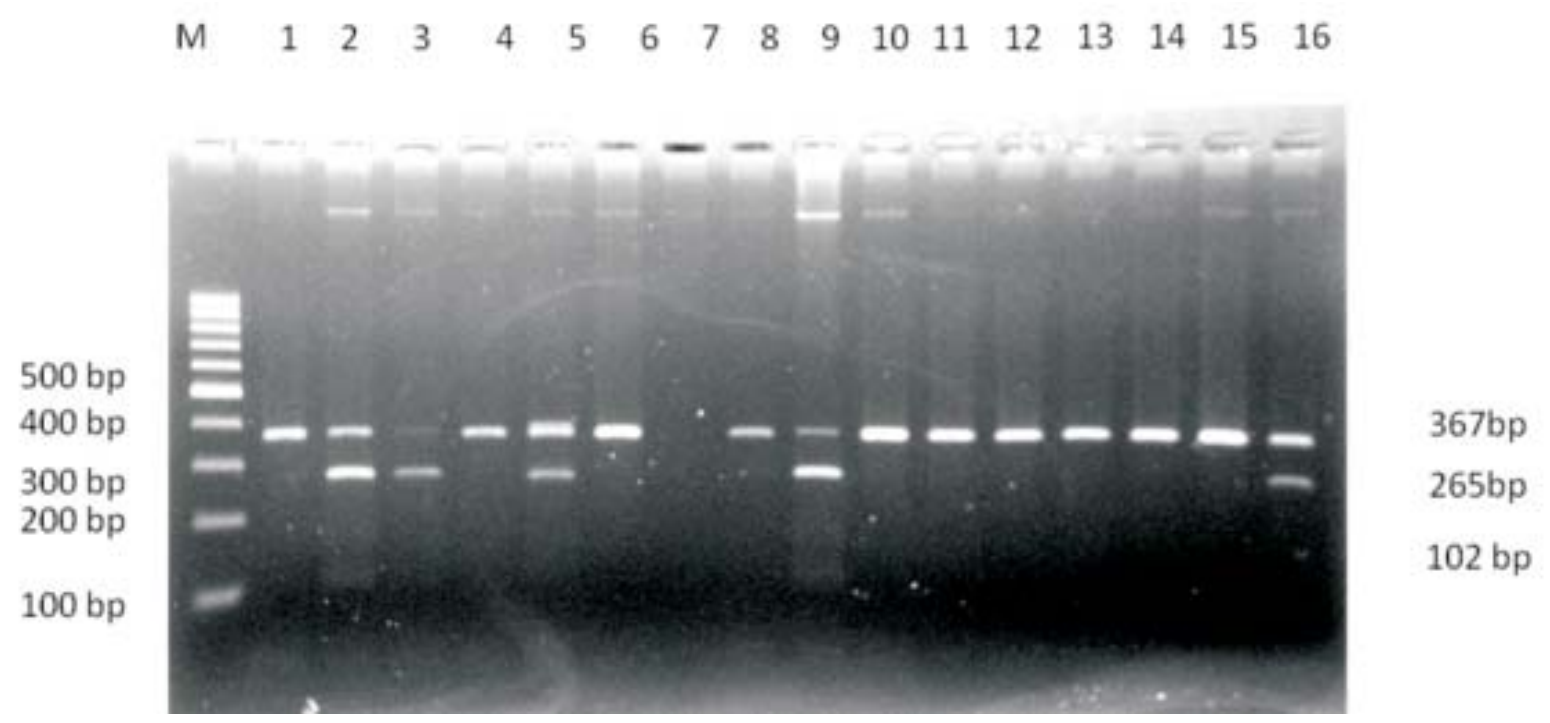

Figure 1.The PCR-RFLP pattern for IGFBP2 gene intron 2 region with Eco72 I restriction enzyme. $\mathrm{M}=$ markers. No.1,4,6,10-15 = CC genotype samples. No.3 = TT genotype samples. No. $2,5,9,16=\mathrm{CT}$ genotype samples. 
The 367 bp fragment was digested with Eco72 I restriction enzyme. The digested PCR products had fragment sizes of $367 \mathrm{bp}$ for the CC genotype, $265 \mathrm{bp}$ and $102 \mathrm{bp}$ for the TT genotype, and a combination of 367, 265 and 102 $\mathrm{bp}$ for CT genotype. These genotypes were named according to a mutation of nitrogen base from $\mathrm{C}$ (cytosine) to $\mathrm{T}$ (thymine). The Kampong chicken population was screened by PCR-RFLP.

The study found the c.1032C $>$ T SNP in the intron 2 of IGFBP2 gene. The allele $\mathrm{C}$ frequency of Kampong, Merawang and Sentul was lower than the allele T frequency. On the other hand, the allele $\mathrm{C}$ frequency of Pelung was higher than the allele $\mathrm{T}$ frequency. The allele $\mathrm{C}$ frequency of Pelung was the highest among five distinct populations. The allele T frequency of Sentul was the highest among five distinct populations (Table 1). On the other hand, the allele T frequency of Sentul was the highest among five distinct populations. Pelung is one of local chickens that has bigger skeletal traits than the others.

IGFBP2 is one of the principal binding proteins secreted by differentiating white preadipocytes. IGFBP2 has a potential role in the development of obesity. Wheatcroft et al. (2007) reported that an overexpression of IGFBP2 was associated with the reduction of susceptibility to obesity and improvement of insulin sensitivity in rat. Chicken IGFBP2 gene is highly expressed in many tissues of embryos and consists of four exons and spans more than 38 kb on chromosome 7 (GGA7) (Schoen et al., 1995).

Li et al. (2006) reported that allele A was associated with high skeletal measurements. The result of chi-square $\left(\mathrm{X}^{2}\right)$ test showed that the distribution of genotypes derived from second intron of IGFBP2 gene in Kampong, merawang, pelung and broiler population was in HardyWeinberg equilibrium. The population of sentul chicken was not in Hardy-Weinberg equilibrium. A certain population was in Hardy-Weinberg equilibrium if the genotype frequencies and allele frequencies were constant from one generation to the next generation resulted from gametes fussion randomly in large population size (Allendorf et al., 2007).

\section{Association of IGFBP2 Gene SNP with Growth and Body Composition}

The IGFBP2 polymorphism was generally significantly associated with body composition. There were significant associations between the IGFBP2 polymorphism and BW, CW, BrW, BrMW, PmiW, LW and WW. The PmaW was not significantly different among three genotypes. Kampong Chicken with the IGFBP2TT genotype had higher BW, CW, BrW, LW, and WW than two another genotypes. Kampong Chicken with the IGFBP2-CC genotype had higher BrMW and PMiW than two another genotypes. Kampong Chicken with the IGFBP2$\mathrm{CT}$ genotype was the lowest in all parameters. This might indicate that there are negative effects of heterosis (Table 2).

The study of the candidate gene is one of primary methods to find QTL responsible for genetic variation intraits of interest and to determine whether specific genes are related to economic traits in farm animals (Rothschild and Soller, 1997; Li et al., 2003). A previous study has shown that a QTL for carcass weight was mapped (about 2.3 to $29 \mathrm{Mb}$ ) on GGA7 (De Koning et al., 2003), which cover the chicken IGFBP2 gene (23 to $24 \mathrm{Mb})$. In addition, Ikeobi et al. (2002) showed that the QTL for fat deposition was mapped between marker brackets LEI0064 and ROS0019 (75 kb to $27 \mathrm{Mb}$ ) on GGA7 in the chicken linkage map, which cover the chicken IGFBP2 gene (23 to $24 \mathrm{Mb}$ ).

Li et al. (2006) reported that the c. $1032 \mathrm{C}>\mathrm{T}$ SNP associated with growth, skeletal measu-

Table 1. The frequency of alleles in kampong chicken population

\begin{tabular}{lccccccc}
\hline Line & $\mathrm{n}$ & $\mathrm{CC}$ & $\mathrm{CT}$ & $\mathrm{TT}$ & $\mathrm{C}$ & $\mathrm{T}$ & $X^{2}$ \\
\hline Kampong & 83 & $0.337(28)^{1}$ & $0.386(32)$ & $0.277(23)$ & 0.530 & 0.470 & 4.24 \\
Merawang & 20 & $0.150(3)$ & $0.450(9)$ & $0.400(8)$ & 0.375 & 0.625 & 0.03 \\
Sentul & 30 & $0.200(6)$ & $0.167(5)$ & $0.633(19)$ & 0.283 & 0.717 & $10.44^{*}$ \\
Pelung & 19 & $0.474(9)$ & $0.474(9)$ & $0.052(1)$ & 0.711 & 0.289 & 0.44 \\
Broiler & 9 & $0.778(7)$ & $0.222(2)$ & $0.000(0)$ & 0.889 & 0.111 & 0.14 \\
\hline
\end{tabular}

*Means within a row with no common superscript are different $\mathrm{X}_{0,05(1)}=3.84$.

1 Numbers shown in parentheses are the number of individuals with the specified genotype. 
Table 2. Effect of The IGFBP2 genotype on growth and body composition traits in Kampong chicken (Means \pm SE)

\begin{tabular}{lccc}
\hline & \multicolumn{3}{c}{ Genotype } \\
\cline { 2 - 4 } Traits $^{1}$ & CC $(22)^{2}$ & CT $(23)$ & TT $(14)$ \\
\cline { 2 - 4 } & $1697.41 \pm 225.39^{\mathrm{ab}}$ & $1585.30 \pm 161.91^{\mathrm{a}}$ & $1740.07 \pm 213.43^{\mathrm{b}}$ \\
\hline BW $^{3}$ & $1096.09 \pm 205.22^{\mathrm{ab}}$ & $1017.39 \pm 157.07^{\mathrm{a}}$ & $1151.36 \pm 220.94^{\mathrm{b}}$ \\
CW & $274.41 \pm 40.18^{\mathrm{ab}}$ & $251.70 \pm 37.22^{\mathrm{a}}$ & $277.43 \pm 33.50^{\mathrm{b}}$ \\
BrW & $195.63 \pm 29.46^{\mathrm{a}}$ & $172.00 \pm 30.53^{\mathrm{b}}$ & $189.69 \pm 34.79^{\mathrm{ab}}$ \\
BrMW & $136.63 \pm 19.15$ & $123.10 \pm 21.23$ & $134.31 \pm 25.01$ \\
PmaW & $59.01 \pm 11.82^{\mathrm{a}}$ & $48.90 \pm 11.50^{\mathrm{b}}$ & $55.37 \pm 13.17^{\mathrm{ab}}$ \\
PmiW & $400.27 \pm 69.92^{\mathrm{ab}}$ & $381.39 \pm 60.78^{\mathrm{a}}$ & $430.14 \pm 69.95^{\mathrm{b}}$ \\
LW & $139.64 \pm 22.05^{\mathrm{ab}}$ & $128.39 \pm 17.50^{\mathrm{a}}$ & $146.86 \pm 25.12^{\mathrm{b}}$ \\
WW &
\end{tabular}

a,b Means within a row with no common superscript are different $(P<0.05)$.

$1 \mathrm{BW}=$ body weight, $\mathrm{CW}=$ carcass weight, $\mathrm{BrW}=$ breast weight, $\mathrm{BrMW}=$ breast muscle weiht, $\mathrm{PmaW}=$ pectoralis major weight, $\mathrm{PmiW}=$ pectoralis minor weight, $\mathrm{LW}=$ leg weight, $\mathrm{WW}=$ wings weight.

2 Numbers shown in parentheses are the number of individuals with the specified genotype.

3 All of traits are in grams.

rements and body compositions traits in the F2 population of NEAU chickens. In the previous study, the homozygous chickens for the B allele were the highest for growth traits and the lowest for skeletal measurement traits. On the other hand, the homozygous chickens for the A allele were the lowest for the body composition traits.

\section{CONCLUSION}

The population of Kampong chicken based on IGFBP2 gene polymorphism was polymorphic. Three genotypes (CC, CT, and TT) were found in this study. On average, Kampong chickens with the IGFBP2-CT genotype grew lower than the others.

\section{SUGGESTION}

All of these results showed that the c. $1032 \mathrm{C}>\mathrm{T}$ SNP of IGFBP2 intron 2 region could be possible as a candidate gene useful for altering growth rate and body composition.

\section{ACKNOWLEDGMENTS}

The authors gratefully acknowledge the member of Animal Breeding and Genetic Community of Animal Production and
Technology in Bogor Agricultural University for breeding the chickens on farm. This research was supported by Ministery of Research and Technology No. 25/SEK/INSINAS/PPK/I/2014 (InSINas Project 2014) and Ministery of Education and Culture No. 081/SP2H/PL/ Dit.Litabmas/VI/2014 (PMDSU Project 2014).

\section{REFEERENCES}

Allendorf FW, Luikart G. 2007. Conservation and the Genetics of Population. $1^{\text {st }}$ ed. UK. Wiley-Blackwell. Pp. 94-97.

Chesik D, De Keyser J, Wilczak N. 2007. Insulinlike growth factor binding protein-2 as a regulator of IGF actions in CNS: implications in multiple sclerosis. Cytokine Growth Factor Rev 18(3-4): 267-278.

Chorev M, Carmel L. 2012. The functions of introns. Front Genet 3: 55

Deeb N, Lamont SJ. 2002. Genetic architecture of growth and body composition in unique chicken population. J Hered 93: 107-118.

DeKoning DJ, Windsor D, Hocking PM, Burt DW, Law A, Haley CS, Morris A, Vincent J, Griffin H. 2003. Quantitative trait locus detection in commercial broiler lines using candidate regions. J Anim Sci 81: 11581165 . 
Drop SL, Schuller AG, Lindenbergh-Kortleve DJ, Groffen C, Brinkman A, Zwarthoff EC. 1992. Structural aspects of the IGFBP family. Growth Regul 2: 69-79.

Eckstein F, Pavicic T, Nedbal S, Schmidt C, Wehr U, Rambeck W, Wolf E, Hoeflich A. 2002. Insulin-like growth factor-binding protein-2 (IGFBP-2) overexpression negatively regulates bone size and mass, but not density, in the absence and presence of growth hormone/IGF-I excess in transgenic mice. Anat. Embryol (Berl.) 206: 139-148.

Ikeobi CO, Woolliams JA, Morrice DR, Law A, Windsor D, Burt DW, Hocking PM. 2002. Quantitative trait loci affecting fatness in the chicken. Anim Genet 33: 428-435.

Kim, JW. 2010. The endocrine regulation of chicken growth. Asian-Aust J Anim Sci 23: 1668-1676.

Leach RM, Richards MP, Praul CA, Ford BC, McMurtry JP. 2006. Investigation of the insulin-like growth factor system in the avian epiphyseal growth plate. Domest. Anim. Endocrinol 33: 143-153.

Lei MM, Nie QH, Peng X, Zhang DX, Zhang XQ. 2005. Single nucleotide polymorphisms of the chicken insulin-like factor binding protein 2 gene associated with chicken growth and carcass traits. Poult Sci 84: 1191-1198.

Leng L, Wang S, Li Z, Wang Q, Li H. 2009. A polymorphism in the 32 -flanking region of insulin-like growth factor binding protein 2 gene associated with abdominal fat in chickens. Poult Sci 88: 938-942.

Li H, Deeb N, Zhou H, Mitchell AD, Ashwell CM, Lamont SJ. 2003. Chicken quantitative trait loci for growth and body composition associated with transforming growth factorâ genes. Poult Sci 82: 347-356.

Li ZH, Li H, Zhang H, Wang S, Wang Q, Wang Y. 2006. Identification of a single nucleotide polymorphism of the insulinlike growth factor binding protein 2 gene and its association with growth and body composition traits in the chicken. J Anim Sci 84: 2902-2906.
Lu FZ, Jiang ZY, Wang XX, Luo YH, Li XF, Liu HL. 2010. Role of the insulin-like growth factor system in epiphyseal cartilage on the development of Langshan and Arbor Acres chickens, Gallus domesticus. Poult Sci 89: 956-965.

Martin A, Dunnington EA, Gross WB, Briles WE, Briles RW, Siegel PB. 1990. Production traits and alloantigen systems in lines of chickens selected for high or low antibody responses to sheep erythrocytes. Poult Sci 69: 871-878.

Nataamijaya AG. 2010. Native chickens' potential development for supporting farmers' welfare improvement. J Litbang Pertanian 29: 131-138. (In Indonesian).

Oh Y, Nagalla SR, Yamanaka Y, Kim HS, Wilson E, Rosenfeld RG. 1996. Synthesis and characterization of insulinlike growth factor binding-protein (IGFBP)-7: Recombinant human mac25 protein specifically binds IGF-I and IGF-II. J Biol Chem 271: 3032230325.

Rechler MM. 1993. Insulin-like growth factor binding proteins. Vitam Horm 47: 1-114.

Riztyan, Katano T, Shimogiri T, Kawabe K, Okamoto S. 2011. Genetic diversity and population structure of Indonesian native chickens based on single nucleotide polymorphism markers. Poult. Sci 90: 2471-2478.

Rothschild MF, Soller M. 1997. Candidate gene analysis to detect genes controlling traits of economic importance in domestic livestock. Probe 8: 13-20.

Rothschild MF, Soller M. 1997. Candidate gene analysis to detect genes controlling traits of economic importance in domestic livestock. Probe 8: 13-20.

Sambrook J, Fritschi EF, Maniatis T. 1989. Molecular cloning: a laboratorymanual. New York. Cold Spring Harbor Laboratory Press. Pp. 1.25-1.28.

Schoen TJ, Mazuruk K, Waldbillig RJ, Potts J, Beebe DC, Chader GJ, Rodriguez IR. 1995. Cloning and characterization of a chick embryo cDNA and gene for IGF-binding protein- 2. J Mol Endocrinol 15: 49-59. 
Shimasaki S, Ling N. 1991. Identification and molecular characterization of insulin-like growth factor binding proteins (IGFBP-1, 2, -3, -4, -5 and -6). Prog Growth Factor Res 3: 243-266.

Sri-Sudaryati, Sidadolog JHP, Wihandoyo, Artama WT, Maharani D. 2013. The effect of Insulin like Growth Factor Binding Protein 2 Gene on Kampong Chicken Growth Rate. Int J Poult Sci 12(8): 495500 .
Wheatcroft SB, Kearney MT, Shah AM, Ezzat VA, Miell JR, Modo M, Williams SC, Cawthorn WP, Medina-Gomez G, Vidal-Puig A, Sethi JK, Crossey PA. 2007. IGF binding protein-2 protects against the development of obesity and insulin resistance. Diabetes 56: 285-294.

Zhao XH, Li MY, Xu SS, Liu GJ. 2015. Single nucleotide polymorphisms in IGFBP-2 gene and their associations with body weight traits on Jinghai Yellow chicken. Brazilian J Poult Sci 4: 497-502. 